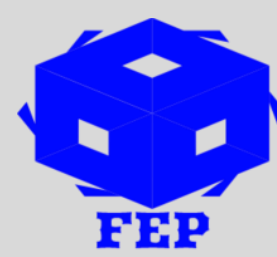

\title{
HECTIC NEWS IN INTERNET: CONFLICT ISSUES NORTH KOREA - SOUTH KOREA (DISCOURSE ANALYSIS ON NORTH - SOUTH KOREAN CONFLICT ON THE INTERNET)
}

\author{
Ibrahim T.I. Ukka ${ }^{1}$ \\ ${ }^{1}$ School of Journalism and Information Communication, \\ Huazhong University of Science and Technology, Wuhan, China.
}

\section{*Corresponding Author: Ibrahim T.I. Ukka}

Corresponding Author Email: ibrahimokah@ @ust.edu.cn

Article Received: 15-05-19 Accepted: 15-07-19 Published: 05-08-19

Licensing Details: Author retains the right of this article. The article is distributed under the terms of the Creative Commons Attribution-NonCommercial 4.0 License (http://www.creativecommons.org/licences/by-nc/4.0/) which permits non-commercial use, reproduction and distribution of the work without further permission provided the original work is attributed as specified on the Journal open access page.

\begin{abstract}
Conflict is an event that often the pros and cons and both causalities and material causalities. Indonesia is a country that has diverse culture, religious, and political perspective as well as a variety of social status that can cause a variety of views among the community. Internet today has become one of the means to provide information to the public. Coverage of all events happening in the world today would be very easy to access via the internet with up to date from time to time. Topics of conflict will be a very interesting issue for everyone in any country it belongs, where one of them is the country of Indonesia. Some media have their own opinions in response to the impact of the conflict between North Korea and South Korea. Some experts argue that the conflict has a positive function and negative one. However, the mindset of conflict theory opposites with structural functional theory. Functional Theory and structural theory, both equally likely to focus on their own variables and ignore variables of concern to other theories. In an effort to reconcile these two theories, the conflict can contribute to the integration and reverse integration can also result in conflict (Bolter and Grusin, 2000).
\end{abstract}


This research uses discourse analysis to answer the problem. Its typically, the expansion of the meaning of the term is associated with a broader context which affects the meaning of the term is associated with a broader context which affects the meaning of a whole series of expressions.

Internet gives impacts to the conflict between North - South Korean. They give an up to date information as long as the conflict has attended. The conflict news from internet can be able to access faster than other medias. It will influence the stabilization and continuing of its conflict. Internet has big playing role in communication politics among both country North and South Korean.

Keywords: Conflict, Communication, Politics, Internet, Information

\section{Background}

\section{INTRODUCTION}

Conflict is an event that often raises the pros and cons and both casualties and material casualties. Indonesia is a country that has diverse cultures, religions, and political perspective as well as a variety of social status that can cause a variety of views among the community.

Multicultural Indonesia's make Bhineka Tunggal Ika as the State motto, still often experience tension and friction between groups in society because of differences in ethnicity, race, and religion. So the issue of conflict will be news that warm to be listened by society Baran, and Davis, 2003).

Internet today has become one of the means to provide information to the public. Coverage of all events happening in the world today would be very easy to access via the internet with up to date from time to time. Topics of conflict will be a very interesting issue " for everyone in any country it belongs, where one of them is the country of Indonesia.

When this has been a lot of social blog that became a forum for public discussion as a means to express thoughts or opinions about any events that happened today. Each Media Newspapers have their own discussion forums on the Internet to share opinions with their readers, both online and through the comments (message).

Tribunnews.com, Jakarta raised discourse: Conflict among allied, North Korea and South Korea might become a big conflict because look at the history backround of the conflict two countries in the aftermath of World War II. Suara Merdeka Cyber News picked up the discourse: The Effect of Conflict on the Korean peninsula. North Korean military artillery ATTACK (North Korea) to region Yeonpyeong Island on Tuesday (11/23/10) referred to as the beginning of a new round of conflict on the Korean peninsula. Reuters launched the attack killed a South Korean marines and wounded dozens of soldiers and other civilians (By Hernandez Bagaskoro). Bandung, Kompas.com - If a war between South Korea and North Korea broke out, inflation is directly in the country is not expected to occur. However, the war will cause inflation to imports (imported inflation).

Some media newspapers have their own opinions in response to the impact of the conflict between North Korea and South Korea. It will effects the cyber who read the news and build varies of opinions. Then it is be able to make a conflict continues into solving problem or becoming ruin. 


\section{Hypothesis}

The hypothesis that researcher declares in this research as follows (Entman 1993) :

1. There are some impacts of conflict news specially in internet media as its function in communication politic.

2. The conflict news will influence the performance of the conflict itself.

3. Internet as media in communication politics has some playing role in performance of the North - South Conflict that it will be progress or regress.

\section{Problem Statement}

Based on the research background, the problem statement are structured as follows:

1. How the impact of conflict news specially in internet media as its function in communication politic?

2. What is the influence of the performance of the conflict itself?

3. What is the playing role of internet as media in communication politics performance of the North - South Conflict?

\section{Problem Limitation}

There are many media specially internet that serve the information about the conflict of North Korean and South Korean. Therefore, the researcher limits her analysis only in three news media in electric media named internet, those are : Tribunnews.com, Cyber News, and Kompas.com.

\section{Research Objective}

Related to the problem statements above, the research objective are arranged as follows :

1. To describe the performance of internet as mass media in communication politic.

2. To know whether the internet that present conflict news of North Korean and South Korean influence the progressing or regressing of the conflict itself.

3. To find the playing role of internet as mass media in communication politic in presenting North Korean - South Korean conflict.

\section{Benefits of the Research}

1. Communication learners who study communication knowledge.

The students of communication department in social politics faculty must be comprehended about how to communicate with others. Partially, this research is aabout communication politics. We need to know how to interact in politic. Because it will be different if we involve in communicating politics. It needs arranged language and competence to express their needs in negotiating or getting case fire, diplomatic chat, etc. It is not as easy as we imagine before. The negotiate are going to involve many people or parties. The negotiate could be succeed and failed. It depends on the competence of the people who getting involve in diplomatic negotiate.

Communication politics is not needed only in the government scale but in the smallest scale such as in family discussion, school, company, etc. If we as a student has already understood and comprehended how to build a good communication in politics, it will help us to enter the real world and face the challenge in communication specially if we want to attend in politics field.

2. Other researchers. 
This research can infuse to conduct such a kind of research in other way of objects of research or in higher level like involving not only describe but also compare, etc. The result of this research will be beneficial for another researcher as an additional references specially for dealing with communication politics.

\section{THE THEORY}

\section{Conflict}

"Conflict theories: Explanations about the nature, progress, and Consequences of social conflict. The most prominent theories have been developed by Karl Marx, Georg Simmel, Lewis Coser, and others. Marx hypothesized Would That conflict eventually leads to the overthrow of the power group, leading to a classless, conflict-free society. Simmel and Coser sugest That conflict is not inherently bad and serves Such Important functions as solidifying the in-group, Increasing group cohesiveness, and mobilizing the energies of group members."(Barker, 1987, p. 31).

Some experts argue that the conflict has a positive function, even the adherents of Marxism defends a fairly extreme stance, namely that the conflict is the only one necessary condition to achieve progress and exclusive community. This establishment is supported by the philosophy of Karl Marx, the philosophy of dialectical materialism and historical materialism. However, this can not be accepted by scholars of non-Marxist, which states that the conflict has a positive function (in addition to negative function), but not in an absolute sense.

Social conflict that became the object of social science is social conflict as a social fact that really happened and can be observed. In this social conflict involves two parties, and each side tries to make others powerless. Conflict theory is built on the basis of "paradigm of social facts", unlike the structural functional theory(Stanley J. Baran, 2010).

However, the mindset of conflict theory conflict with structural functional theory. Character theory of conflict that results in extreme opposite thoughts with structural functional theory is Ralph Dahrendorf, among others (Ritzer, 1980: 52):

(1) According to the structural functional theory, people are in a static condition or rather move in a state of equilibrium; while according to the theory of conflict is the opposite; people always are in the process of change that is marked by continuous conflict between its elements.

(2) In the structural functional theory every element is considered to provide support for stability, is the theory of conflict to see that every element contributing to social disintegration.

(3) The theory of structural functional view of community members informally bound by the norms, values and public morality, were assessing the regularity theory of conflict inherent in society it is only due to pressure or coercion of power from above by the ruling class.

In addition to the followers of the theory of conflict that his thinking quite a contrast to the structural functional theory, there is also a conflict theorist who are more moderate in relation to these structural functional theory, including the Lewis A Coser.

According to Coser, conflict can be functional in a positive or negative. Functional positively impacted if the conflict is to strengthen the group, the opposite one is negative if it moving 
against the structure. In relation to the existing value system in society, conflict is negative functional when attacking a core value. In the event of conflict between a group with other groups, conflict can be positive functional because it will help the stabilization of structural boundaries and enhance integration within the group.

Another expert is Pierre van den Berghe (Ritzer, 1980: 63). Berghe tried to reconcile these two perspectives. He showed some similarities between the analyses of both approaches, both are holistic because both view society as composed of parts that are interconnected with each other, and the main attention is addressed to the relationship between the parts. Functional theory and the theory of structural conflict, both equally likely to focus on their own variables and ignore variables of concern to other theories. In an effort to reconcile these two theories, Berghe assume that the conflict can contribute to the integration and reverse integration can also result in conflict.

\section{Value of conflict}

View of value conflict emerged after World War II. This view provides a critique of the views of social pathology and deviant behavior. In the view of conflict of values, the concept of sickness or social expectation is a subjective concept, so it is difficult to be a reference in understanding social problems. Thus, it is conceivable that a distortion of the rules does not always equal to the failure of regulation in controlling social life. Society is dynamic, and growing increasingly complex, so it does not close the possibility of a deviation rule, because the offender used to live in another group whose values are different, even contradictory. This mindset explains, that social problems occur when two or more groups with different values converge and compete. To explain these terms to take a sample of cases of home owners with tenants. Homeowners want the rent increased, while it expects tenant's rents low. Such a situation can bring conflict, and conflict caused by different values and interests (LaRose and Straubhaar, 2006) .

The consequences of further polarization in the society can arise. Social problems may not occur if the strong are willing to sacrifice for the weak (compromise). Social problems will only arise when the powerful use their power to defend its interests. In reality, the situation of conflict to develop into three possibilities namely consensus, trading and power. In this connection homeowners and tenants who serve as an example the case, then the alternative consensus occurs when the landlord and tenant agree that the increase in the number of rental homes that are not too large still to be understood together. Trading, if homeowners are willing to suppress increase in rental houses with certain compensation. Power, if the homeowner expel tenants who do not meet the demands of rental increases.

Social problems arising from the conflict of values can also be found in a complex society who knows of the issue of minority and majority. Minorities are the group of people who do not receive equal treatment compared to other groups of people in the same society(Moore 2014).

In connection with the discussion of this issue is known by the three terms of racial minorities, ethnic minorities and assimilation. Racial minority consists of a group of people who has an innate biological characteristic such as skin color. Ethnic minority consists of a group of people who has different cultural performances with those used by most members of society. Cultural aspects which could form a minority of this type is a language, religion, 
national origin, common history and so forth. If members of minority groups from racial and ethnic backgrounds use or adopt the characteristics of a culture that is the mainstream in a broad community environment, through adaptation to their cultural patterns are "unique" culture pattern into a majority group, or through hybridization, then there was a process of assimilation.

Of course, among the three phenomena's that potential conflict is grows minority racial and ethnic minorities, are likely functional assimilation of the structure because it encourages integration.

\section{Communication Politic}

The production, dissemination, procession and effects of information, both through media and interpersonally, within a political context. This includes the study of the media, the analysis of speeches by politicians and those that are trying to influence the political process, and formal and informal conversations among members of the public, among other aspects (Wolfsfeld, 1999:2).

As with many terms in social science, political communication has also been difficult to define. For instance, Robert E. Denton and Gary C. Woodward in their book Political Communication in America characterize political communication in the form of intentions of its senders to influence the political environment. In their words "the crucial factor that makes communication 'political' is not the source of a message, but its content and purpose." Brian McNair provides a similar definition when he writes that political communication is "purposeful communication about politics." For McNair this means that this not only covers verbal or written statements, but also visual representations such as dress, make-up, hairstyle or logo design. With other words, it also includes all those aspects that develop a "political identity" or "image".

There are many academic departments and schools around the country that specialize in political communication. These programs are housed in programs of communication, journalism, and political science, among others. The study of political communication is clearly interdisciplinary.

\section{METHOD}

Discourse analysis, in the simplest sense is the study of language units above the sentence. Typically, the expansion of the meaning of the term is associated with a broader context which affects the meaning of a whole series of expressions. Analysts examine the larger discourse of language when they are interlocked. Some discourse analysts consider a wider context for understanding how context affects the meaning of the sentence (Deborah, 2004). Qualitative discourse analysis more emphasis on the meaning of the text than the sum of unit categories, such as in content analysis. Quantitative content analysis is used to dissect the text content of communication that is manifest (apparent), while discourse analysis would focus on the message that is latent (hidden).

As already mentioned, discourse analysis is not only raised in the study of language, but also in many other studies field. In linguistics, discourse analysis refers to the study of language units above the sentence that focuses on a higher level of grammatical relations (grammatical), in sociology, discourse analysis refers to the study of social ties in the context 
of language usage. If in social psychology, discourse analysis refers to the study of structure and form of conversations or interviews, in political science, discourse analysis refers to the study of language usage and their correlation practice with power. It seems clear, is used in field of any kind studies, terms of discourse analysis would include the study of language in use.

The research object in this research is media mail and blog articles that blog social conflict between North Korea and South Korea at this time (November, 2010) the theme of the impact of the conflict of North Korea and South Korea. During that month, the media reported several warm incidents on the development of an increasingly heated conflict between both states. The writings will serve as the primary data and then analyze using discourse analysis techniques.

\section{The Influence of Internet}

\section{DISCUSSION}

The influence of the Internet has caused a change in the way we shop, communicate, and learn.Prior to the Internet, everyday tasks such as banking, paying bills, and shopping took time outside the home. With the Internet, online banking allows people to keep their personal finances on track twenty-four hours a day. While this is nothing new, banks did offer phone services to do the same functions, the fact that online banking can now be combined with online bill paying, late payments are quickly becoming a thing of the past. Even online shopping can save time and energy. Shopping for the latest trends in clothes? Hop on line and pick outfits from your favorite stores. No more going to the mall, finding a parking space, then not being able to find your size. Online shopping gives more options and realtime inventory of items. A mall store may have limited space to display all the trends, but an online store is only limited by the size of their imagination. Online shopping has even progressed into the supermarket realm. Sit at home on a Thursday evening and order food for your Saturday backyard bar-ba-que for delivery on Saturday morning. No more pushing a cart around a big box store, and lugging heavy plastic bags to you car. Door to door delivery of groceries means you never have to go to the store again (Hanitzsch 2004, pp. 483-495). The Internet has also closed the gap for many families separated by the miles. While the US Postal Service has progressed since the days of the Pony Express, the Internet has made stamps and phone calls nearly obsolete. During World War II, letters to and from troops were censored and shrunk to nearly microfiche size. With all the processing required, letters often took weeks or months to arrive. Today, a quick email takes seconds to convey feelings of fear and joy to love ones around the world. As the Internet becomes utilized more for emails, emails themselves have become more sophisticated. Pictures and short movies now zip around the world at lightning speed. Want to show the newest member of the family to Grandma in Florida? Take some video and attach it to an email. For less then the cost of a plane ticket, she can count all the fingers and toes herself.

The Internet is probably most famous for the ability to spread information, fact or fiction. We were once limited to news editors of a local paper, then to national cable news. Now anyone can search the globe, visit local papers in foreign countries, and see the views of all sides. This ease of information has also brought with it a large amount of hoaxes, money schemes, and fallacies. Internet websites offering quick money, instant 
weight loss, and Nostradomises predictions sit side be side websites providing legitimate health information, historic facts, and online stock trading Galtung's (1998).

The Internet has also helped increase the entire computer hardware industry. To compete in the latest online gaming, the fastest computers are often needed. The hardware industry constantly pushes bigger, faster, and more expensive equipment, even to people that already own a computer (Sutherland, 1998). The hardware industry may push speed of hardware as a reason to upgrade, but the average Internet user will always be limited by the speed of their Internet connection. Dial-up Internet access is the same speed whether using a four year old slow computer, and the latest model from the Dell's and Gateway's of the world (LaRose and Straubhaar, 2006:164-165).

In this research internet is very important to inform anything what had happened in conflict country. In the case, conflict o north - south Korean. The news via internet direct the cyber or users to get information in fast ways. Only few second, we can understand and know much about something happened in other universe. The conflict, its attends in regional scale, Asia, but people from the another world can see the conflict by browsing internet. The information of conflict will give positive and negative effect to North and South Korean and other countries. Sometimes the news of conflict is used to conquer its enemy. It will influence the stabilization of both country and surroundings (Galtung's, 1986).

\section{The Playing role of internet media in communication politic in North Korean - South Korean Conflict}

Based on explanation above we know that Korean Conflict (war) have effect for the both countries and Asian country. There are some news related with Korean Conflict as follows :

1. Kompas.com

RUMGAPRES/ABROR RIZKI Presiden Susilo Bambang Yudhoyono.

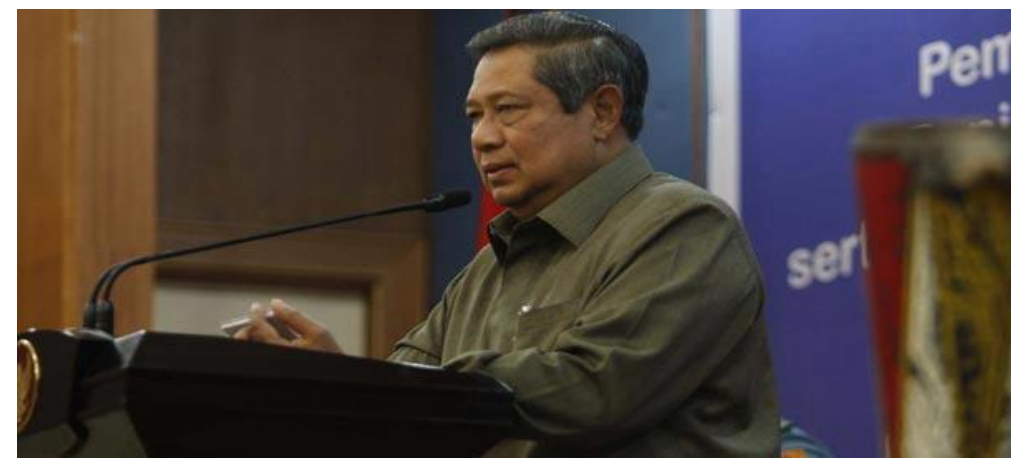

About :

- China supports North Korean

- US and Japan behind South Korean

- Korean Crisis, President gave his commit

The news is stated as follows:

- JAKARTA, KOMPAS.com - Presiden Susilo Bambang Yudhoyono mengaku prihatin atas konflik yang bergejolak di Semenanjung Korea. Jika berlanjut, kata Presiden, konflik tersebut dapat meluas dan melibatkan negara-negara lain di sekitar Semenanjung Korea.

- Tembakan serangan militer artileri yang bisa memicu konflik yang lebih besar. -- Presiden SBY 
- "Indonesia sangat prihatin dengan insiden di Semenanjung Korea Utara dan Korea Selatan. Bahkan saat ini telah menimbulkan korban jiwa dan sipil. Tembakan serangan militer artileri yang bisa memicu konflik yang lebih besar," kata Presiden ketika membuka sidang kabinet paripurna di Kantor Presiden, Jakarta, Kamis (25/11/2010).

Presiden berharap, Perserikatan Bangsa-Bangsa dan negara-negara kunci dapat mencegah terjadinya konflik yang lebih luas di antara kedua negara. Presiden berharap konflik tersebut dapat segera diakhiri.

Presiden mengatakan, konflik kedua negara ini dapat dibawa pada pertemuan puncak Asia Timur pada 2011. Agenda pertemuan puncak tersebut adalah dialog politik keamanan regional. Pada pertemuan tersebut, Indonesia bertindak sebagai tuan rumah.

- $\quad$ "Saya pandang tepat membahas itu karena akan dihadiri 10 negara ASEAN dan .....

http://internasional.kompas.com/read/2010/11/25/15501047/SBY.Prihatin.Konflik.di.Semena njung.Korea

Based on the news above, Mr. Susilo Bambang Yudoyono as a President of Indonesia gives his sympathy to the Korean Conflict. In his statement, he has already deed a free active politics system or we called Politik bebas akttif. It means that Indonesia doesn't choose any block, Indonesia is netral and active in peaceful activities among the country in the world.

President Susilo Bambang Yudoyono in his communication politic also gave an idea that it will be better if every nation involve to solve the Korean War. It can be attend at East Asia Meeting 2011. Hopefully, the case, conflict between North - South Korean will get a good commitment and both country get could live peacefully.

2. Tribunnews.com

Tribunnews.com - Senin, 20 Desember 2010 15:22 WIB

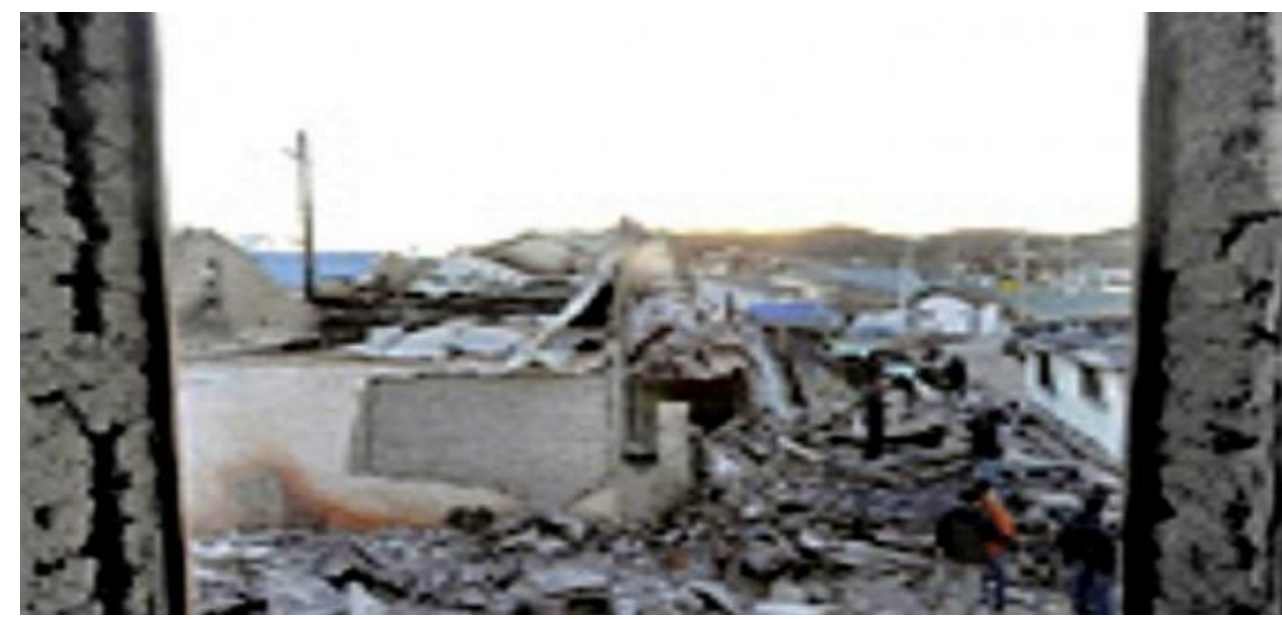

The news is about: Korean War

- There must a freedom between North and South Korean

- South Korean Reject Attending Dialogue with North Korean

- South Korean Open a dialogue with North Korean 
- Russian praise Korean attitude in facing South Korean

- South Korean gave charismas tree to gain North Korean

- North Koeran has been progress in solving strained situation

TRIBUNNEWS.COM SEOUL --- Dewan Keamanan (DK) PBB gagal menyamakan sikap atas ketegangan di Semenanjung Korea. Meski demikian DK akan terus berupaya mendamaikan kedua belah pihak. Situasi ini muncul saat Korea Selatan (Korsel) bersiap melakukan latihan perang lagi di dekat perbatasan. Kondisi ini berpotensi untuk kembali menimbulkan serangan dari Korea Utara (Korut) seperti pada akhir November lalu.

Dewan keamanan PBB telah menggelar sidang di Markas Besar PBB di New York, Minggu (19/12/2010) waktu setempat. Dan para anggota utama DK tidak mampu bersepakat untuk mengatasi konflik antar dua negara Korea.

Laman stasiun televisi Arirang mengungkapkan, para diplomat anggota-anggota DK-PBB telah menghabiskan waktu tujuh jam untuk berdebat, namun belum ada hasil.

"Tampaknya bisa diprediksi bahwa perbedaan-perbedaan yang masih ada belum bisa dijembatani," kata Duta Besar (Dubes) AS untuk PBB, Susan Rice, seperti yang dikutip laman stasiun televisi Press

Dubes Rusia untuk PBB, Vitaly Churkin, juga mengatakan bahwa pembicaraan di DK belum ada hasil. Namun, dia menyatakan bahwa para anggota akan melanjutkan negosiasi untuk mengatasi perbedaan sikap.

Belum berhasilnya DK-PBB menyamakan sikap disebabkan oleh perbedaan pandangan antara sejumlah anggota utama yang punya hak veto (hak yang bisa digunakan untuk menggugurkan suatu rancangan resolusi).

China dan Rusia ingin agar Korsel menahan diri untuk tidak lagi menggelar latihan perang, yang akan dimulai Senin (20/12/2010). Sebaliknya, AS keberatan dengan permintaan China dan

Rusia.

Sebagai sekutu Korsel sejak Perang Korea 1950-1953, AS mendukung latihan perang, yang penting sebagai upaya antisipasi serangan dari Korut, yang selama ini mendapat dukungan dari

China.

Dalam sidang, AS justru mempertanyakan sikap ambigu Rusia dan China, yang dinilai tidak menyalahkan Korut atas krisis yang terjadi, namun meminta Korsel menahan diri untuk tidak membalas serangan dari Pyongyang pada 23 November lalu. 
Sebaliknya, delegasi AS, Inggris, Prancis, Jepang, dan Korsel mendukung usulan rancangan resolusi dari Inggris, yang isinya menyalahkan Korut sebagai penyulut krisis dan mengecam serangan artileri ke Pulau Yeonpyeong. Usulan resolusi dari Inggris itu justru ditolak Rusia dan China.

Sementara itu, selain meminta kedua Korea saling menahan diri, Rusia mengusulkan agar Sekretaris Jenderal PBB mengirim utusan khusus ke Seoul dan Pyongyang untuk meredakan ketegangan, sehingga tidak mengarah ke perang terbuka.

\section{Penulis: OMDSMY Novemy Leo | Editor: OMDSMY Novemy Leo http://www.tribunnews.com/2010/12/20/dewan-keamanan-pbb-gagal-sikapi- konflik-korea}

Based on the news above Tribunnews informed that United nation will take a part to solve the conflict in Korean. The news gave impact to reader that United Nation as world organization has been proved participated to give ways reaching Korean peacefully. It helps the readers to know the condition of Korean conflict. So it decreases the worry of civil citizen who faces and involves in conflict directly or undirectly.

TRIBUNNEWS.COM, JAKARTA --- Jalan satu-satunya menyelesaikan perselisihan Korea Utara dan Korea Selatan hanyalah melalui diplomasi, perundingan enam pihak (six party talk) dengan campur tangan Perserikatan Bangsa-Bangsa.

Artinya, saat ini belum waktunya mereka membuat perjanjian atau jalan keluar yang baru untuk masalah di Semenanjung Korea. Demikian Menteri Luar Negeri Indonesia, Marty Natalegawa, di Jakarta, Jumat (26/11/2010).

"Jalan yang paling tepat untuk mengatasi masalah ini adalah melalui six party talk dan PBB. Bukan waktunya untuk menciptakan langkah baru," ujarnya.

Diplomasi memiliki kontribusi yang besar dalam perdamaian di kawasan. PBB, ujarnya, juga memiliki peran yang besar. "PBB harus menyuarakan protesnya," ujar Natalegawa.

Natalegawa menjelaskan bahwa konflik yang terjadi di Korea tersebut adalah salah satu konflik tradisional yang terdapat di abad ini.

"Kita sedang berada di dunia transformasi, di mana permasalahan dan tantangan yang kita hadapi saat ini adalah seputar keamanan, perubahan iklim, serta krisis pangan dan air bersih. Konflik Korea adalah salah satu bentuk konflik tradisional yang masih ada," ujarnya.

Menurutnya, negara-negara di dunia juga memiliki tanggung jawab dalam mengatasi masalah ini. Dia menyerukan masyarakat internasional memberikan kutukan yang keras terhadap serangan

Korut. 
"Semoga situasi bisa terkendali dan tidak meningkat menjadi konflik yang lebih besar," harap Natalegawa. Konflik di Korea baru-baru ini terjadi ketika Korea Utara menyerang Pulau Yeonpyeong di Korea Selatan, Selasa (23/11/2010). Korsel lalu membalas serangan itu. Akibat konflik itu, dua marinis dan dua warga sipil Korsel tewas terhantam artileri.

Based on the information about Abroad Minister of Indonesia, Marty Natalegawa also gave statement that it must attend good diplomatic speaking between North - South Korean. The world should concern with the conflict and participate actively. Now days, countries in a whole of the world face some problem of nation stabilization, climate changing, food crisis, and clean water. Korean conflict is one kind of traditional conflict. So, every country must take a part to finish this conflict.

\section{Cybernews}

\section{Suara Merdeka Cyber News}

About: The Effect of Conflict on the Korean peninsula.

North Korean military artillery ATTACK (North Korea) to region Yeonpyeong Island on Tuesday (11/23/10) referred to as the beginning of a new round of conflict on the Korean peninsula. Reuters launched the attack killed a South Korean marines and wounded dozens of soldiers and other civilians (By Hernandez Bagaskoro)

The news above states the condition of conflict between north Korean and South Korean. Hopefully by the reported above, the United Nation and all of part of the world care and concern with this problem in order to get solving problem between both country.

\section{CONCLUSION}

As we have been so far, many of the claims made by various media about the Internet's effect on Korean politics and conflicts. For example, the impact of generational differences, fuelled by the Internet during the 2002 Korean election, may not have been as important as the traditional regional differences. It is, probably too early to conclude that the internet is not significant force in politics and conflicts. The potential of internet media is in terms of mobilization, quick communication and up - to - date reporting of conflicts while they actually happen, something newspaper, because of the lead time between news gathering and printing, are usually unable to match.

It is in doubt that the Internet has impacted our politics and nation stabilization in very short period of time. However, whether such changes are merely evolutionary or revolutionary is still not clear. Recent observations and studies of Internet in communication politics are of the opinion that the Internet in communication politics influence is not

\section{References}

Baran, S.J. \& Davis, D. K. (2003). Mass Communication Theory: Foundation, Ferment, and Future. Canada: Thomson Learning Academic Resource Center. 
Bolter, J.D., \& Richard, G.(2000). Remediation: Understanding New Media. Cambridge, MA: MIT Press.

Coser, L. A., \& Rosenberg, B. (1976). Sociological Theory (Fourth Edition). USA: Macmillan Publishing Co., Inc.

Dahrendorf, R. (1983). Konflik dan konflik dalam masyarakat industri (sebuah analisa kritik). Terjemahan Ali Mandan dari Judul aslinya: Class and Classs Conflict in Industrial Society. Jakarta: Penerbit CV. Rajawali.

Deborah, T. (2004). Discourse Analysis. Working Paper. Georgetown University

Entman, R. M. (1993). Framing: Toward clarification of a fractured paradigm. Journal of communication, 43(4), 51-58.

Galtung, J. (1986). On the role of the media in worldwide security and peace. In T. Varis (Ed.), Peace and communication (pp. 249-66). San Jose, Costa Rica: Universidad para La Paz.

Galtung, J. (1998). Peace journalism: What, why, who, how, when, where. Paper presented in the workshop, "What are journalists for?" TRANSCEND, Taplow Court, UK.

Hanitzsch, T. (2004). Journalist as peacekeeping force? Peace journalism and mass communication theory. Journalism studies, 5/4, 482-493.

http://bisniskeuangan.kompas.com/read/2010/11/26/15432792/Perang.Korea.Sebabkan.Impor ted.Inflation-5

http://en.wikipedia.org/wiki/Political_communication

http://suaramerdeka.com/v1/index.php/read/cetak/2010/11/27/131197/10/Efek-Konflik-diSemenanjung-Korea.

http://www.tribunnews.com/2010/11/24/konflik-korea-makin-besar-bila-as-ikut

LaRose, \& Straubhaar, (2000). Communications Media in the Information Age. United States of America: Wadsworth, a division of Thomson Learning.

LaRose and Straubhaar, (2000). Communications Media in the Information Age. United States of America: Wadsworth, a division of Thomson Learning.

Moore, C. (2014). The Mediation Process: Practical Strategies for Resolving Conflict, San Francisco, CA: Jossey-Bass.

Robert L. B. 1(987). The Social Work Dictionary, NASW, Silver Spring, Maryland.

Stanley, J. B. (2010). Introduction to Mass Communication: Media Literacy and Culture, McGraw-Hill, New York.

Sutherland. W.J, (1998). Ecological Census Techniques: a handbook. Cambridge University Press, Cambridge

Wolfsfeld, G. (1999). Media and Political Conflict: News from the Middle East. 